\title{
The Impact of Perceived Justice on Students' Negative Emotional Responses during Service Recovery
}

\author{
Steven kayambazinthu Msosa ${ }^{1}$ \\ ${ }^{1}$ Department of Marketing, Mangosuthu University of Technology, Durban, South Africa \\ Correspondence: Steven kayambazinthu Msosa, Department of Marketing, Mangosuthu University of Technology, \\ Durban, South Africa. E-mail: msosa.steven@mut.ac.za.
}

Received: June 17, 2020

Accepted: July 29, 2020

Online Published: July 30, 2020

doi:10.5430/ijhe.v9n5p230

URL: https://doi.org/10.5430/ijhe.v9n5p230

\begin{abstract}
This study sought to evaluate the impact of perceived justice on students' negative emotional responses during service recovery. Quantitative, descriptive multi-variate regression analysis and a cross-sectional study were undertaken using a judgmental sample of 430 students drawn from three public Higher Education Institutions in South Africa. The results of this study showed that all the dimensions of justice, viz. procedural, distributive and interactional justice, have a negative and significant impact on negative emotions. The findings of this study could assist higher education institutional managers to interrogate the fairness of the processes used in Higher Education Institutions (HEIs) to address student grievances because they have a negative and significant impact on students' negative emotions.
\end{abstract}

Keywords: distributive justice, interactional justice, procedural justice, negative emotion, higher education institutions

\section{Introduction}

In Africa, the demand for free Higher Education (HE) and other social services such as health and basic education has been a subject of debate since the 1960s. As a matter of fact, the cost of Higher Education in South Africa has been a major challenge. Moreover, students have expressed their displeasure at the rising costs of Higher Education and the lack of financial aid to support individuals from disadvantaged backgrounds (Langa et al, 2016). The struggle for the emancipation of South African students against injustice dates back as far as 1976 when students took to the streets against oppression in the education sector by the apartheid regime. In recent times, students' concerns about poor service; the slow pace of transformation; and the alienation of students from disadvantaged backgrounds in Higher Education Institutions (HEIs) have been characterized by protests, strikes and violence (Rapatsa, 2017).

For instance, any attempt by universities to raise tuition fees has led to students' dissatisfaction with universities and the call for the Fees must Fall protests which have left indelible marks of extensive damage on campus infrastructures across the country. The Minister of Higher Education and Training, Dr. Blade Nzimande, noted that "It cannot be accepted from us as a government that student protests are resulting in violence and the destruction of universities' property that belongs to the public of South Africa and future generations to come. We have agreed that law enforcement agencies must work with us in protecting the property, students and the staff as a whole. We have been worried about a particular fringe within students who have captured and diverted genuine students' demands for their own ends, using violence and damaging property" (Ministry of Higher Education and Training, 2016: 1).

At the tertiary level, there are glaring differences between the best performing and lowest-level institutions. The historically white institutions continue to dominate in terms of performance in the South African higher education sector compared to black dominated historically disadvantaged institutions. As a result, there has been a spillover of resentment on many issues across universities in South Africa. Higher education institutions have been riddled with protest in opposition to rising tuition and the need for transformation. This has led to campus shutdowns, affected inbound mobility to South Africa, and derailed the researchers progress towards completion of their work on campus (Macha \& Kadakia, 2017). Student protests are an indication of the shortcomings and failure by higher education institutions to address student's concerns relating to transformation. Financing of studies is one of the problems students are grappling with. The current tuition fees for students are very low compared to European or North American standards, but for most of the students in South Africa, they are high and beyond the reach of many families 
(Tjønneland, 2017). It is against this background that a study has to be conducted to analyse the impact of perceived justice on students' negative emotional responses during service recovery.

\section{Literature Review}

\subsection{Social Exchange and Equity Theory}

Adams (1963) claims that people develop their beliefs on what is considered to be fair. In this regard, they compare their exchanges with others who are known as referents. If they believe that the treatment received is inequitable compared to others, they are motivated to do something about it and to seek justice. Feelings of anger, disappointment and offence are often triggered by the injustice that students perceive concerning the institution's policies, complaints-handling process and methods used to address service failure (del Rio-Lanza et al., 2013). Thus, when students feel that the university has deviated from the set or expected standards and that they have not been treated fairly, their negative emotions escalate (Andreassen, 2001).

\subsection{Negative Emotions}

Emotions are defined as "a mental state of readiness that arises from cognitive appraisals of events or thoughts; has a phenomenological tone; is accompanied by physiological processes; is often expressed physically (e.g. in gestures, posture, facial features); and may result in specific actions to affirm or cope with the emotion, depending on its nature and meaning for the person having it" (Bagozzi et al., 1999, p. 184). Negative emotions are triggered when there is a deviation from the expected service or initial service failure, as well as during service recovery (double deviation). As a result, students experience anger, frustration, annoyance and in some cases, rage. Negative emotions can only be triggered by two episodes, viz. service failure and service recovery. Thus, students' negative emotions that emanate from the service failure experience are undesirable for HEIs, whereas those that are caused by a service recovery experience can either be negative or positive (Casado-Diaz et al., 2005). Consequently, Valentini and Polyakova (2016) posit that students are likely to get emotional twice if there is a double deviation or consecutive failure, which may result in the university or institution being negatively evaluated.

In HEIs, when students' expectations are not met, they become angry. They engage in negative publicity and retaliatory behaviour. Therefore, when students protest against something that has gone wrong, it justifies the unforgiving and retaliatory behaviour narrative. It is believed that young people have pride and do not forgive easily. They regard themselves as strong human beings with a lot of inner drive to combat obstacles, such that they do not need to be compassionate towards the offender (i.e. the employee who has given them the bad service or is not responsive to their needs). They engage in retaliatory, vengeful acts, rather than seeking peace and psychological equilibrium in their relationship with the service provider (Tsarenko \& Tojib, 2012). McColl-Kennedy and Smith (2006) argue that anger is the most frequently experienced negative emotion during service encounters. High levels of anger and dissatisfaction have negative consequences for the service provider, such as lower returns on investment, decreased brand loyalty and the spread of negative word-of-mouth. Aggrieved students may decide to react differently to service encounters which were not good or where service failure occurred. This behaviour ranges from complaining to faculty managers or an employee in a calm manner to screaming or verbal abuse towards the employee, complaining to a third party such as the Department of Higher Education and Training (DHET) or seeking revenge through actions such as damaging institutional property.

\subsection{Perceived Justice}

Being fairly treated by service employees in a service recovery scenario raises students' perceptions of quality and justice (Chen et al., 2014). Student perceptions of how fairly they have been treated during the service recovery process after lodging a complaint will affect their satisfaction and intention to recommend the institution (Siu et al., 2013). Complaints from students are an indication that they are concerned about fairness. Thus, students expect to be treated fairly with respect to the outcome and process used during the service recovery process, as well as the interpersonal treatment received from employees in their quest to address service failure. Ultimately, fair treatment is crucial for effective service recovery (Wilson et al., 2012).

Perceived justice is used during service recovery to ascertain if the recovery efforts are fair and specific to the transaction under consideration (Kwon \& Jang, 2012). Gelbrich and Roschk (2011) have warned institutions not to only concentrate on the service recovery effort, but to also focus on the perception of justice or fairness. Ultimately, it is the student who decides what is considered to be fair and not the institution. Consequently, institutions that ignore students' perceptions of justice may wrongly assume that they have properly addressed student problems whilst the student is not happy and may be forced to take unfavourable actions. Students perceive the dimensions of justice (interactional, procedural and distributive justice) differently, based on the quality of the service rendered during 
service recovery (Jung \& Seock, 2017). Thus, distributive justice is the fairness shown by the institution concerning the tangible outcome of the service recovery process and is used to pacify a dissatisfied student. Distributive justice may include monetary and non-monetary compensation, viz. credit, discounts, refunds, replacement, coupons and an apology (Boshoff, 2014).

Procedural justice refers to the fairness of the process used to address student complaints or problems. Thus, Procedural justice encompasses policies and structural considerations that may influence the outcome (McColl-Kennedy \& Sparks, 2003), whereas Interactional justice refers to the fairness of the interaction between the student and employees of the institution during the service recovery process (Ngahu et al., 2016). Therefore, students should be handled fairly and provided with a solution or assistance that is in tune with their perception of justice. Moreover, it must also be noted that perceptions concerning justice between the institution and students vary. In this regard, service providers are advised to channel their resources to understand student expectations and what they regard or consider as fair in order to internalise their needs in service processes or, at the very least, assist them to comprehend that the solution given is the most appropriate option for their predicament (Fierro et al., 2011).

The quality of interpersonal interactions may signal to students that the service provider cares. As such, it is important to treat students with respect, friendliness and politeness during a service encounter. The cost of interacting with students in a way that raises their dignity is not going to be as high as the cost of satisfying students either through Procedural or Distributive justice. Therefore, it is imperative for higher education institutions to train service employees so that they have the necessary communication skills to provide adequate assistance in the event of a service breakdown (Fang et al., 2011). In addition, trust and respect are pertinent in a relationship between the service provider and student, especially in cases where the student expects to enjoy certain privileges of occupying a higher social position (i.e. as a president of the students' union or a $\mathrm{PhD}$ student) than the service employee. Therefore, according to Chen et al. (2014), the implication of infringing this social order is that the student will perceive that they have been treated unfairly.

\subsection{Relationship between Perceived Justice and Negative Emotions}

The three dimensions of justice (procedural, interactional and distributive justice) are not independent of each other, such that where the procedures and interactions in which the recovery takes place are considered to be unfair, it may not be sufficient to provide the student with a fair outcome such as compensation for the factual loss and an apology to reduce the emotional stress of the student (Gronroos, 2007). Students evaluate the recovery effort based on the interaction (interactional justice) and outcome (distributive justice). Therefore, Distributive justice (DJ) and Interactional justice (IJ) are not unrelated constructs, but are facets of the same construct, justice. However, DJ does not entail favourable IJ in that Distributive justice may be fair even if Interactional justice is flawed (McCollough, Berry \& Yadav, 2000).

Previous research on the impact of perceived justice (distributive justice, interactional justice and procedural justice) on negative emotions has found a negative and significant relationship (Chebat \& Slucarczyk, 2005; del Rio-Lanza et al., 2013; and Urueña López \& Hidalgo Nuchera, 2014). Furthermore, a few studies have paid attention to negative emotions during service recovery (del Rio-Lanza et al., 2013). Chebat and Slucarczyk (2005) and Schoefer and Ennew (2005) conducted notable studies that investigated negative emotions and perceived justice during service recovery. Currently, there is a dearth of research on negative emotional responses during service recovery in the higher education sector. Hence this study seeks to address this gap in the literature. The study explored the relationship between perceived justice and negative emotions during service recovery. As shown in Figure 1, the hypotheses for the present study are:

H1 : Distributive justice has a negative and significant relationship with negative emotions.

$\mathbf{H 2}$ : Interactional justice has a negative and significant relationship with negative emotions.

H3 : Procedural justice has a negative and significant relationship with negative emotions. 


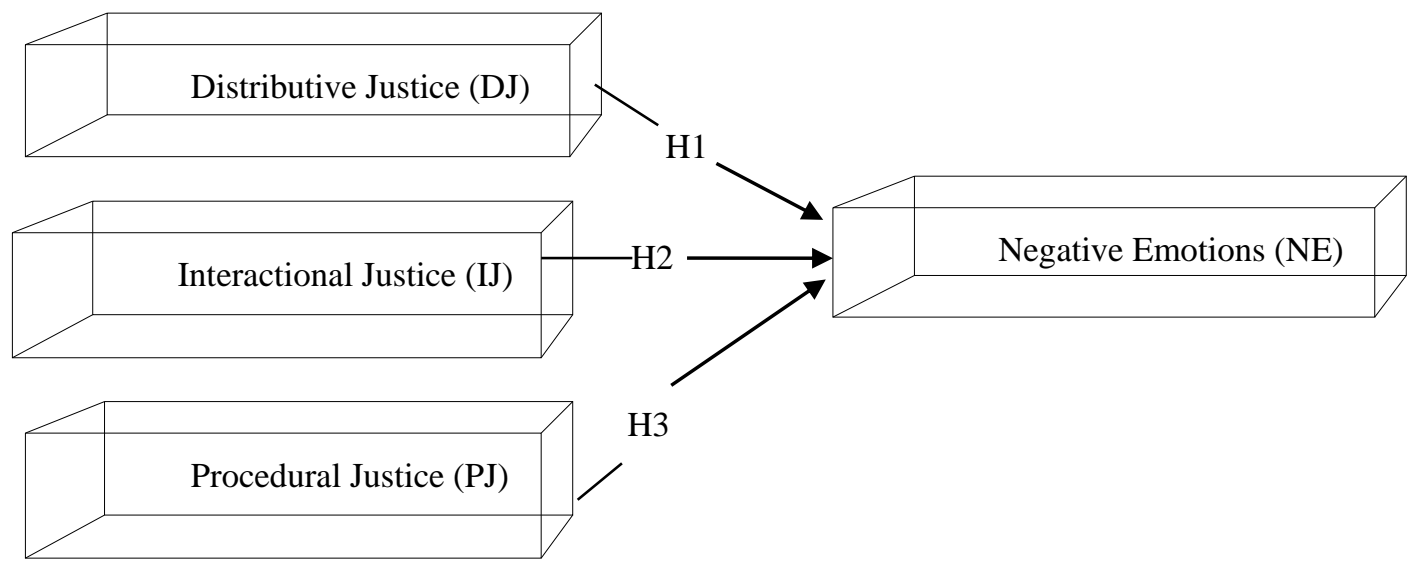

Figure 1. Research Model

\section{Methodology}

A questionnaire survey design based on the recall of critical incidents was utilised so that students can evaluate the study based on real or lived campus experiences rather than on simulated scenarios which may not form part of their daily campus life. Thus, structured questionnaires which rely on a recall method to evaluate students' perceptions of justice and negative emotions were deemed appropriate because simulated scenario-based methods are limited in their application and may not assist in ascertaining the conditions and decisions that form part of campus life (May, 2011). In this regard, a questionnaire with a 5-point Likert Scale (strongly disagree, disagree, uncertain, agree and strongly agree) was used to gauge student feelings. The variables used in this study were adopted from previous studies. For instance, Justice dimensions (Smith et al., 1999; Severt, 2002; Ramadan, 2012) and negative emotions (Casado-Diaz et al., 2005; Kim \& Tang, 2016; Varela-Neira et al., 2010).

\subsection{Sample and Procedure}

A purposive sampling technique was adopted to select elements of the sample. This sampling technique was used to select respondents based on their experience with the service recovery process in the three designated universities. According to Churchill et al. (2010), Purposive sampling uses the researcher's discretionary choice to select respondents based on certain characteristics that are deemed relevant to the study. Furthermore, a quantitative, descriptive cross-sectional study was undertaken. Gilbert (2008) has noted that a typical social survey is cross-sectional in nature, implying that respondents are asked similar questions at the same time, such that the time difference in terms of questionnaire administration is considered irrelevant. A total of 430 students from three public universities in South Africa, specifically from the KwaZulu-Natal province, participated as respondents.

\subsection{Data Analysis}

The data collected was analysed using descriptive and inferential statistics. The XLSTART Statistical Software was used to facilitate the analysis. Furthermore, the multivariate analysis of variance (MANOVA techniques) and multivariate regression were used as viable tools in multivariate generalisation. These methods describe how elements in a vector of variables respond simultaneously to changes in others. In addition, MANOVA shows the effect of treatments on several criterion variables individually, as well as the relationships amongst the number of criterion variates (Bray \& Maxwell,1982). This study examined the impact of the independent variable (procedural, interactional and distributive justice) on the dependent variable (negative emotion).

\subsection{Reliability and Validity}

Bolarinwa (2015) avers that reliability is the extent to which a questionnaire, test, observation or any measurement procedure produces the same results on repeated trials. The measure of reliability assesses the stability of a test over time. Furthermore, Gliem and Gliem (2003) advise that when using Likert-type scales, it is imperative to calculate and report Cronbach's alpha coefficient for internal consistency reliability for any scales or sub-scales one may be using. To test reliability, the study used Cronbach's alpha.

\subsection{Sub-Scale Construction}

Following the pre-data analysis, sub-scales were constructed and analysed item by item according to the planned sections of the questionnaire. These were: distributive justice (DJ); procedural justice (PJ) and interactional justice (IJ). The reliability of the sub-scales was evaluated by means of Cronbach's alpha, which is appropriate for Likert scale 
items. The results are presented in Table 1 below. The Cronbach's alpha reliability scores for each variable were: distributive justice $=0.763$; procedural Justice $=0.759$; interactional Justice $=0.722$; and negative emotions $=0.852$. Thus, the values of the overall Cronbach's alpha (0.706) in this study were above 0.70 and as a result, the reliability scores were adequate and acceptable (Bryman \& Bell, 2015).

Table 1 . Test for Reliability

\begin{tabular}{lllll}
\hline $\boldsymbol{\alpha}$ & $\mathbf{0 . 7 0 6}$ & & & \\
\hline Cronbach's alpha & DJ & PJ & IJ & NE \\
& 0.763 & 0.759 & 0.722 & 0.852 \\
\hline
\end{tabular}

DJ=Distributive Justice; PJ= Procedural Justice; IJ= Interaction Justice; NE= Negative Emotions.

\subsection{Test for Validity}

According to Gay et al. (2012), validity is the degree to which data can accurately gauge what the researcher is trying to measure. There are various types of validity tests, namely discriminant validity, content validity, face validity and construct validity (Andres, 2012). Discriminant validity may exist when measures of different variables are significantly but only slightly correlated with each other, or not correlated with each other. Engellant et al. (2016) describe discriminant validity as the extent that measures of different constructs diverge or minimally correlate with one another. To test validity, the study used discriminant validity mainly through the correction test. A discriminant analysis was conducted to ensure that each item involved in the study only measured one construct at a time. Table 2 below indicates that discriminant validity is supported because all the respondents' correlation coefficients are less than 5, confirming that each item did in fact measure only one construct at a time. Theoretically, one would expect a moderate level of correlation between the scales measured.

Table 2. Pearson correlation coefficients of determinants for Discriminant validity

\begin{tabular}{lllll}
\hline Variables & DJ & PJ & IJ & NE \\
\hline DJ & $\mathbf{1}$ & & & \\
PJ & 0.744 & $\mathbf{1}$ & & \\
IJ & 0.834 & 0.647 & $\mathbf{1}$ & $\mathbf{1}$ \\
NE & $0.554^{*}$ & $0.419^{*}$ & $0.364^{*}$ & $\mathbf{1}$ \\
\hline
\end{tabular}

Correlation are significant at the 0.05 level (2-tailed)

Overall, Table 2 shows a positive correlation of a large effect size amongst the variables in the model, except for a positive small effect with negative emotion. Field (2009) postulates that $0<|\mathrm{r}|<0.3$ means small effect, $0.3<|\mathrm{r}|<0.7$ means medium size and $|r|>0.7$ means large size. The constructs involved in the model are therefore distinct from each other and the discriminant validity of the constructs is supported. Since the reliability and the validity of the measurements have been confirmed, the relationship amongst the variables was subsequently addressed.

\subsection{Biographical Data}

In terms of the biographical profile of the respondents, the results showed that 55.3 percent of were male and 44.7 percent were female. The findings reveal that the majority of respondents were studying in their 3rd year (35.8 percent), while 21.9 percent of the sample respondents were studying in 1st year. There is an equal percentage of the sample respondents who were studying in 4 th year and 2 nd year $(20.2$ percent $)$. Furthermore, the findings reveal that the majority of students in this study were registered for Humanities courses (50.9 percent), followed by those registered for Science courses (30.2 percent), while those registered for Commercial courses equated to 18.8 percent.

\section{Results}

The descriptive statistics summary for the various dimensions of justice and negative emotion is presented in Table 3 below. The table shows the mean and the standard deviation extracted from the scales. 
Table 3. Descriptive Statistical summary of the study variables

\begin{tabular}{llllll}
\hline Likert Scale & DJ & PJ & IJ & NE \\
\hline Strong Disagree & 3.193 & 3.086 & 3.109 & 3.102 & \\
Disagree & 3.049 & 3.021 & 2.951 & 3.088 & \\
Uncertain & 3.040 & 2.947 & 2.928 & 2.947 & \\
Agree & 3.193 & 2.807 & 3.093 & 3.102 & \\
Strongly Agree & 3.049 & 2.835 & 2.979 & 3.088 & \\
Mean (M) & 3.105 & 2.939 & 3.012 & 3.066 & 3.030 \\
Std. Dev (S.D) & 0.081 & 0.119 & 0.084 & 0.067 & 0.022 \\
\hline
\end{tabular}

The score ranges from 1 to 5 . A higher score indicates a more favourable response. From Table 3, the average mean of 3.03 and the Standard deviation of 0.022 imply that many respondents tend to agree with the importance/significance of perceived justice (distributive, procedural and interactional justice) on students' negative emotional responses during service recovery. Table 4 depicts the model predictor value parameters.

Table 4. Model predictor analysis of variance (NE)

\begin{tabular}{llllll}
\hline & DF & Sum of squares & Mean squares & F & $\begin{array}{l}\text { Pr }>\text { F } \\
\text { (Sig.) }\end{array}$ \\
\hline Model & 6 & 10900.640 & 1816.773 & 4.840 & $\mathbf{0 . 0 0 8}$ \\
Error & 13 & 4879.360 & 375.335 & & \\
Corrected Total & 19 & 15780.000 & & & \\
Computed against model $Y=\operatorname{Mean}(Y)$ & & &
\end{tabular}

As shown in Table 4, the probability value for the F-test statistic (0.008) is less than 0.05 (5\% level of significance), which indicates that the model is adequate. This means that the combination of the predictors significantly combines to contribute to NE.

Table 5 presents the multivariate regression coefficients for perceived justice (IJ, PJ and DJ) as predictors of students' negative emotion. The overall MANOVA test of significance of $(0.002)$ shows that there is a statistically significant association between the interaction variables and the dependent variable at the 0.05 significance level.

Table 5. Regression result of the of impact perceived justice (DJ, IJ, PJ) on negative emotion

$\begin{array}{lll}\text { Regression } & & \begin{array}{l}\text { Standardised } \\ \text { coefficients }\end{array} \\ \text { Coefficients } & \text { Unstandardised coefficients } & \end{array}$

\begin{tabular}{llclllll}
\hline Model & Beta & $\begin{array}{l}\text { Standard } \\
\text { error }\end{array}$ & Beta & $\mathrm{t}$ & $\begin{array}{l}\text { Pr }>|\mathrm{t}| \\
(\text { Sig. })\end{array}$ & Tolerance & VIF \\
Intercept & 82.885 & 21.664 & & 3.826 & $\mathbf{0 . 0 0 2}$ & & \\
DJ & -3.460 & 2.351 & -6.301 & -1.472 & 0.035 & 0.001 & 8.176 \\
PJ & -3.506 & 2.359 & -6.055 & -1.486 & 0.011 & 0.010 & 4.145 \\
IJ & -0.774 & 0.944 & -1.291 & -0.820 & 0.027 & 0.004 & 5.008 \\
DJ*PJ & -0.001 & 0.008 & -0.415 & -0.172 & 0.043 & 0.001 & 9.232 \\
DJ*IJ & -0.020 & 0.017 & -5.582 & -1.155 & 0.021 & 0.001 & 5.807 \\
PJ*IJ & -0.029 & 0.018 & -7.736 & 1.582 & 0.038 & 0.011 & 2.096 \\
\hline $\mathrm{R}^{2}$ & 0.691 & & & & & &
\end{tabular}

Adjusted $\mathrm{R}^{2} \quad 0.548$

a. Dependent Variable: Negative Emotion

b. Predictors: (Constant), procedural, interactional and distributive Justice 
The multivariate regression findings have helped to appreciate the role of an independent variable (distributive, interactional, procedural justice) and their interactive impact on negative emotion. The coefficient of determination $\left(\mathrm{R}^{2}\right)$, which is the squared value of the multiple regression coefficient $(\mathrm{R})$, shows that about $69 \%$ of the variability of the dependent variable (NE) is explained by the 6 explanatory variables. The standardised coefficients beta and p-values have been used in comparing the contribution of each of the independent variables in explaining how significantly more the variable contributes to the predictor NE than what a basic mean would bring. In this regard, the relationship between IJ and negative emotions was evaluated. The findings reveal a negative and significant impact $(\beta=-1.291, \mathrm{t}-\mathrm{value}=-0.820, \mathrm{p}=0.027)$ as indicated in Table 5. Similarly, tests were done to evaluate the impact of DJ on negative emotions. The results reflect a negative and significant impact $(\beta=-6.301, \mathrm{t}$-value $=-1.472, \mathrm{p}=0.035)$. Furthermore, the impact of PJ on negative emotions was assessed. The results emanating from the test reveal a negative and significant impact $(\beta=-6.055, \mathrm{t}$-value $=-1.486, \mathrm{p}=0.011)$. Thus, this implies that all the dimensions of justice viz. procedural, distributive and interactional justice have a negative and significant impact on negative emotions.

\section{Discussion}

The purpose of this study was to analyse the impact of perceived justice on students' negative emotional responses during service recovery. Specifically, the impact of Interactional, Procedural and Distributive justice on negative emotions was evaluated. The findings showed that Interactional justice has a negative and significant impact on negative emotions. The findings are consistent with a study by Chebat and Slusarczyk (2005) which found that Interactional justice has a negative and significant impact on negative emotions. Furthermore, the results of the impact of Distributive justice on negative emotions showed a negative and significant impact. The findings of this study agree with previous studies (Kim \& Tang, 2016; DeWitt et al., 2008) which concluded that Distributive justice has a significant and negative impact on negative emotions.

The current study also showed that the impact of Procedural justice on negative emotions is negative and significant. This finding corroborates a study conducted in the cell-phone industry which found a negative and significant impact of Procedural justice on negative emotions. The result implies that students' perceptions of PJ trigger emotional responses. Therefore, this finding is in line with Cognitive Appraisal and Affect Control theories, which explain that students' emotions emanate from a subjective analysis of experiences or episodes that may occur within their learning environment. Thus, in this study, it appears that perceived Procedural justice represents dimensions of cognitive appraisal that help to explain how students' emotions are awakened by service recovery efforts (del Río-Lanza et al., 2013). Similarly, Kozub et al. (2014) have noted that the use of emotions in this study can assist in providing a better diagnostic framework for comprehending attitudes that students must endure following a consecutive failure, rather than focusing on the cognitive assessment of performance.

\section{Conclusion}

This study has analysed the impact of perceived justice on students' negative emotional responses during service recovery. Based on the findings of this study, it is recommended that employees in universities should be properly trained on how to manage and pacify students' emotions. Moreover, training can enhance employees' performance with respect to the use of justice dimensions and, subsequently, reduce negative emotions. Besides, the management of HEIs is further encouraged to make decisions that are acceptable to both parties. This can be done by involving students in the determination of the outcome. The implication is that when students or the afflicted parties are involved in the determination of the recovery strategy, they may likely accept the outcome as fair.

There is a need to empower university employees so that they can make decisions without the involvement of management. In this regard, management of HEIs should introduce work policies that spell out the line of responsibility and delegation so that members of staff are fully aware of the extent to which they can get involved in decision-making when a student lodges a complaint. This can assist in addressing role conflicts and employees' overlapping responsibilities, which may subsequently lead to procedural injustices when students are not timeously assisted. Thus, any delays in assisting students during service recovery can enhance students' perceptions of unfairness and subsequently, a poorly executed service recovery may trigger negative emotions. In addition, the management of HEIs should train members of staff to enhance their interpersonal communication skills such as empathy and listening, which are facets of Interactional justice. This will in turn help the members of staff to acquire skills that will assist them to manage and explain the service recovery efforts being undertaken by the institution to resolve students' problems. This study has limitations that constrain the generalisation of its findings. The study was conducted at three universities such that the results cannot be generalised beyond the current scope. However, the findings of this study can prove useful to other universities with a similar management architecture or set-up. Future research may also consider 
moderating variables between the three dimensions of perceived justice and negative emotion, such as the length and frequency of the relationship.

\section{References}

Adams, J.S. (1963). Toward an understanding of inequity. Journal of Abnormal and Social Psychology, 67, 422-436. https://doi.org/10.1037/h0040968

Andres, L. (2012). Designing \& doing survey research. Los Angeles: SAGE. https://doi.org/10.4135/9781526402202

Andreassen, T. W. (2001). From disgust to delight: Do customers hold a grudge? Journal of Service Research, 4(1), 39-49. https://doi.org/10.1177/109467050141004

Bagozzi, R. P., M. Gopinath, and P.U. Nyer. (1999). The role of emotions in marketing. Journal of the Academy of Marketing Science, 27(2), 184-202. https://doi.org/10.1177/0092070399272005

Bolarinwa, O. A. (2015). Principles and Methods of Validity and Reliability Testing of Questionnaires Used in Social and Health Science Researches. Nigerian Postgraduate Medical Journal, 22(2015), 195-201. https://doi.org/10.4103/1117-1936.173959

Boshoff, C. (2014). The influence of buffering variables on clients' willingness to engage in retribution behaviour after service failure. South African Journal of Economics and Management, 17(3), 297-309. https://doi.org/10.4102/sajems.v17i3.689

Bray, J.H. and Maxwell, S.E., (1982). Analyzing and interpreting significant MANOVAs. Review of Educational research, 52(3), 340-367. https://doi.org/10.3102/00346543052003340

Bryman, A. and Bell, E., (2015). Business research methods (Vol. 4th). Glasgow: Bell \& Bain Ltd.

Casado-Diaz, A.B., F.J. Mas-Ruiz, and H. Kasper. (2005). Explaining satisfaction in double deviation scenarios: The effects of anger and distributive justice. Instituto Valenciano de Investigaciones Económicas, SA (IVIE).

Chebat, J. C. and W. Slusarczyk. (2005). How emotions mediate the effect of perceived justice on loyalty in service recovery situations: An empirical study. Journal of Business Research, 58(5), 664-673. https://doi.org/10.1016/j.jbusres.2003.09.005

Chen, H., Y.L. Lee and, B. Weiler. (2014). Exploring perceived fairness in hotel service recovery: the case of Kingdom plaza, Wuhan. Asia-Pacific Journal of Innovation in Hospitality and Tourism, 3(1), 1-26. https://doi.org/10.7603/s40930-014-0001-3

Churchill, G.A., T.J. Brown, and T.A. Suter. (2010). Basic marketing research. 7th ed. Mason, Ohio: South-Western Cengage Learning.

del Río-Lanza, A.B., R. Vázquez-Casielles, and AM. Díaz-Martín. (2013). Satisfaction with service recovery: Perceived justice and emotional responses. Journal of Business Research, 62(8), 775-781. https://doi.org/10.1016/j.jbusres.2008.09.015

DeWitt, T., D. T. Nguyen, and R. Marshall. (2008). Exploring customer loyalty following service recovery the mediating effects of trust and emotions. Journal of Service Research, 10(3), 261-289. https://doi.org/10.1177/1094670507310767

Engellant, A. K., Holland, D. D. and Piper. R. T. (2012). Assessing Convergent and Discriminant Validity of the Motivation Construct for the Technology Integration Education (TIE) Model. Journal of Higher Education Theory and Practice, 16(1), 37-50.

Fang, Y.H., C.M. Chiu and E.T. Wang. (2011). Understanding customers' satisfaction and repurchase intentions: An integration of IS success model, trust, and justice. Internet Research, 21(4), 479-503. https://doi.org/10.1108/10662241111158335

Fierro, J.J.C., J.M.B. Pineda, R.R. Benítez, and R.V. Carrasco. (2011). Does the customers' educational level moderate service recovery processes? International Journal of Business and Social Science, 2(21), 59-71.

Field, A. (2009). Discovering statistics using SPSS. Sage publications.

Gay, I. R., Mills, G. E. and Airasian, P. W. (2012). Educational Research: Competencies for Analysis and Applications. $10^{\text {th }}$ ed. Bouston: Pearson Education, Inc.

Gelbrich, K. and H. Roschk. (2011). A meta-analysis of organizational complaint handling and customer responses. Journal of Service Research, 14(1), 24-43. https://doi.org/10.1177/1094670510387914 
Gilbert, N. (2008). Researching social life. London: Sage.

Gliem, J.A. and Gliem, R.R., (2003). Calculating, interpreting, and reporting Cronbach's alpha reliability coefficient for Likert-type scales. Midwest Research-to-Practice Conference in Adult, Continuing, and Community Education.

Gronroos, C. (2007). Service management and marketing: Customer management in service competition. $3^{\text {rd }}$ ed. West Sussex: John Wiley \& Sons Ltd.

Jung, N.Y. and Y.K. Seock. (2017). Effect of service recovery on customers' perceived justice, satisfaction, and word-of-mouth intentions on online shopping websites. Journal of Retailing and Consumer Services, 37(1), 23-30. https://doi.org/10.1016/j.jretconser.2017.01.012

Kim, E. and R. Tang. (2016). Rectifying failure of service: How customer perceptions of justice affect their emotional response and social media testimonial. Journal of Hospitality Marketing \& Management, 25(8), 897-924. https://doi.org/10.1080/19368623.2016.1149537

Kozub, K.R., M.A. O’Neill, and A. Palmer. (2014). Emotional antecedents and outcomes of service recovery: an exploratory study in the luxury hotel industry. Journal of Services Marketing, 28(3), 233-243. https://doi.org/10.1108/JSM-08-2012-0147

Kwon, S. and Jang, S.S., (2012). Effects of compensation for service recovery: From the equity theory perspective. International Journal of Hospitality Management, 31(4), 1235-1243. https://doi.org/10.1016/j.ijhm.2012.03.002

Langa, P., Wangenge-Ouma, G. and Jungblut, J. (2016). South Africa and the illusion of free higher education. Available online: https://www.universityworldnews.com/post.php?story=20160223145336908. Accessed 3 March, 2020.

Macha, W and Kadakia, A. (2017). Education in South Africa. Available online: https://wenr.wes.org/2017/05/education-south-africa. (Accessed, 23 July, 2020).

May, T. (2011). Social research: Issues, methods and process. $4^{\text {th }}$ ed. Berkshire: McGraw Hill.

McColl-Kennedy, J.R. and B.A. Sparks. (2003). Application of fairness theory to service failures and service recovery. Journal of Service Research, 5(3), 251-266. https://doi.org/10.1177/1094670502238918

McColl-Kennedy, J.R and A.K. Smith. (2006). Customer emotions in service failure and recovery encounters. In Zerbe, W.J; Ashkanasay, N.M \& Hartel, C.E.J (Ed), Research on emotions in organisations: Individual and organisational perspectives on emotion management and display, Oxford: Elsevier.

McCollough, M.A., L.L. Berry and M.S. Yadav. (2000). An empirical investigation of customer satisfaction after service failure and service recovery. Journal of Service Research, 3(2), 121-137. https://doi.org/10.1177/109467050032002

Ministry of Higher Education and Training. (2016). The cost of damage to property resulting from 2016 students protests. Available from http://sharepoint2013.dhet.gov.za/Parliamentary\%20Matters/November\% 0016/DHET\%20response\%20to\%20PQ\%20833.pdf. Accessed on: 30.12.2016.

Ngahu, C., F. Kibera, and P. Kabonyo. (2016). The influence of interactional justice strategy on recovery satisfaction among customers of mobile money service in Kenya. Journal of Marketing and Consumer Research, 27(2422), 55-61.

Ramadan, A.G.A. (2012). Exploring service recovery and justice theory in the Libyan airline industry. PhD Thesis. University of Gloucestershire.

Rapatsa, M., (2017). Student Activists or Student Anarchists? South Africa's Contemporary Student Protests Reviewed. European Review of Applied Sociology, 10(15), 13-20. https://doi.org/10.1515/eras-2017-0005

Schoefer, K. and C. Ennew. (2005). The impact of perceived justice on consumers' emotional responses to service complaint experiences. Journal of Services Marketing, 19(5), 261-270. https://doi.org/10.1108/08876040510609880

Severt, D.E., (2002). The customer's path to loyalty: a partial test of the relationships of prior experience, justice, and customer satisfaction (Doctoral dissertation, Virginia Tech, Virginia). Available online: https://vtechworks.lib.vt.edu/handle/10919/27191. (Accessed: 16 January, 2020).

Siu, N.Y., T.J. Zhang and C.J. Yau. (2013). The role of justice and customer satisfaction in retention: A lesson from service recovery. Journal of Business Ethics, 114(1), 675-686. https://doi.org/10.1007/s10551-013-1713-3 
Smith, A.K; Bolton, R.N and Wagner, J. (1999). A model of customer satisfaction with service encounter involving failure and recovery. Journal of marketing research, 36, 356-372. https://doi.org/10.1177/002224379903600305

Tjønneland, E.J. (2017.) Crisis at South Africa's universities - what are the implications for future cooperation with Norway? Bergen: Chr. Michelsen Institute (CMI Brief), 16(3), 4.

Tsarenko, Y and D. Tojib. (2012). The role of personality characteristics and service failure severity in consumer forgiveness and service outcomes. Journal of Marketing Management, 9(10), 1217-1239. https://doi.org/10.1080/0267257X.2011.619150

Urueña López, A. and A. Hidalgo Nuchera. (2014). Justice, emotions and satisfaction in complaint behaviour in services. Available from http://oa.upm.es/36316/1/INVE_MEM_2014_189690.pdf, Accessed 10.02.2018.

Valentini, S. and A. Polyakova. (2016). Getting emotional twice: an analysis of patterns of emotional states after failure and recovery. Conference proceedings 2016. La Londe.

Varela-Neira, C.; Vázquez-Casielles and Iglesias, V. R. (2010). Explaining customer satisfaction with complaint handling. International Journal of Bank Marketing, 28(2), 88-112. https://doi.org/10.1108/02652321011018305

Wilson, A., V.A. Zeithaml, M.J. Bitner and D.D. Gremler. (2012). Services marketing: Integrating customer focus across the firm. Berkshire: McGraw Hill. 